\title{
BOND STRESS-SLIP BEHAVIOUR OF CONCRETE AND STEEL UNDER HIGH-LOADING RATES
}

\author{
P. MÁCA, E. PANTEKI \& M. CURBACH \\ Institute for Concrete Structures, Technische Universität Dresden, Germany.
}

\begin{abstract}
Understanding the bond behaviour between reinforcing steel and concrete under high-loading rates is becoming more and more important with increasing frequency of natural disasters, impact loadings and a threat of terrorism. This paper aims to obtain a better understanding of the material interactions between the steel rebar and the concrete in the bond zone under different loading rates. During the experimental program push-in tests were conducted under quasi-static and dynamic loading conditions. Both a servo-hydraulic machine as well as an instrumented drop tower were used during the investigation. Samples with short-bond zone in the middle of a cylindrical specimen were used and only a small reinforcement bar diameter $(10 \mathrm{~mm})$ was investigated. This approach was chosen to ensure constant bond stress distribution and that the failure occurs during the first pass of the stress wave through the bond zone. Throughout the experimental programme the loading rate was varied from $0.01 \mathrm{~mm} / \mathrm{s}$ to 8.3 $\mathrm{m} / \mathrm{s}$. Bond stress-slip relationships in dependence on the bond stress rate are presented in this paper. The results indicate a bond stress dependence on the loading rate although the scattering of the results is quite high. The experimentally determined dynamic increase factor (DIF) for concrete-steel bond stress is around 1.5 which is a value comparable to other authors.
\end{abstract}

Keywords: bond stress-slip relation, bond test, DIF, impact, push-in strain rate.

\section{INTRODUCTION}

The behaviour of a composite material such as reinforced concrete depends on the interaction of its components, that is, steel and concrete. The bond behaviour is usually described as a bond stress corresponding to a certain value of rebar slip. In general, three failure mechanisms can be identified: pure pull-out or push-in, splitting of the concrete cover and the combination of the both mechanisms. The ideal bond behaviour due to short-bond length is usually investigated by the so-called pull-out test [1]. In case of small bar diameters and short-bond lengths the test can be modified to push-in setup without significant influence. This test setup is then more convenient for impact loading measurements.

Many research teams reported that the measured strength of concrete [2] as well as the strength of reinforcing steel $[3,4]$ rise with high-loading rates. This phenomenon is usually called the strain rate effect, and it is summarized for instance in the ACI report on Dynamic Fracture of Concrete [5] and CEB report No. 184 [6]. Usually, the strain rate effect has been studied separately for steel and concrete, and it is significantly different for concrete compressive strength in comparison with tensile strength $[7,8]$. In order to take the advantage of the increased strengths for the design of impact exposed buildings, such as nuclear power plants or rock fall galleries, it is important to ensure that the bond between concrete and steel can also withstand the corresponding loading. 
First studies about the influence of high-loading rates on the bond behaviour of steel and concrete were published by Hansen and Liepins [9] and by Shah and Hansen [10]. They conclude that splitting and cracking are important factors that influence the bond failure. In case of pull-out tests with short-bond zones, four time the reinforcement diameter (ds), they observed $30 \%$ increase in the bond strength capacity which was attributed to the DIF of concrete in compression. A great amount of pull-out tests under dynamic loading conditions was performed by Hjorth [11]. He studied not only the effect of the loading rate but also the effects of the bond zone length. The results for deformed steel showed an increase of the bond strength of up to $30 \%$ for loading rates as high as $1,000 \mathrm{MPa} / \mathrm{s}$. In addition, he concluded that with an increasing concrete compressive strength the sensitivity to the loading rate is lower. The pull-out resistance on cylindrical specimens was measured by Vos and Reinhardt [12, 13]. While the plain bars showed insensitivity to the loading rate the deformed bars showed an increase in the bond strength with increasing loading rate. Both push-in and pull-out behaviour of steel plain and deformed reinforcement bars was studied by Yan in his dissertation [14]. He showed an increase in the bond strength for deformed steel. In addition, he showed greater bond capacity of the push-in tests which is explained by the Poisson's effect of steel in compression. Another series of pull-out tests on cylindrical specimens was performed by Weathersby [15]. Similarly to this research paper, he studied three loading rates with the following loading durations: static (97-713 s), dynamic (31-200 ms) and impact (4-7 ms). For the deformed bars, he measured 100\% increase in the bond strength in case of the impact loading. The concrete cover of the tested specimens was however very small and the dominating failure mechanism was concrete splitting. The resistance of the concrete to splitting is dominated by its tensile strength which is more sensitive to strain rates. This could explain the exceptionally high DIF. This was also confirmed by the research of Solomos and Berra [16] who showed that in case of splitting failure the increase of bond strength is up to $90 \%$ whereas in case of pull-out failure mode, the increase is only $30 \%$.

\section{RESEARCH SIGNIFICANCE}

The main aim of this work is to analyse the influence of high-loading rates on the bond behaviour between reinforcing steel bars and concrete experimentally. For this reason, the bond stress-rebar displacement relation of concrete specimens for different loading rates is measured and compared. Short-bond lengths are investigated to understand the localized bond behaviour. After the bond mechanisms are fully understood the results will be incorporated in a numerical model to predict the behaviour of reinforced concrete at high-loading rates and varying conditions. This model could be used for detailing structures for exceptional loading conditions such as vehicle impacts and explosions.

\section{EXPERIMENTAL PROGRAM}

\subsection{Materials and specimen preparation}

Throughout the experimental investigations normal concrete with a target cube compressive strength of $50 \mathrm{MPa}$ was used. The exact concrete mixture composition is shown in Table 1. The flowability of the fresh concrete varied from 400 to $450 \mathrm{~mm}$. To be able to classify the used concrete basic mechanical properties were measured before the push-in testing. These properties are presented in Table 2 as an average of 6 samples. To monitor the concrete quality throughout the experimental work concrete compressive strength as well as splitting tensile strength was determined with every test series made. 
Table 1: Concrete composition in $\mathrm{kg}$ per $\mathrm{m}^{3}$.

\begin{tabular}{lclll}
\hline $\begin{array}{l}\text { Cement } \\
\text { CEM I 42,5N }\end{array}$ & Sand 0/2 & $\begin{array}{l}\text { Aggregates } \\
2 / 8\end{array}$ & $\begin{array}{l}\text { Plasticizer } \\
\text { FM 30 }\end{array}$ & Water \\
\hline 409 & 942 & 771 & 3.07 & 203 \\
\hline
\end{tabular}

Table 2: Basic mechanical properties of the investigated concrete.

\begin{tabular}{llll}
\hline Property & Value & Standard deviation & $\begin{array}{l}\text { Coefficient of } \\
\text { variation }(\%)\end{array}$ \\
\hline Compressive strength $^{\text {a }}$ & $51.7\left[\mathrm{~N} / \mathrm{mm}^{2}\right]$ & $3.9\left[\mathrm{~N} / \mathrm{mm}^{2}\right]$ & 8 \\
Density & $2,300\left[\mathrm{~kg} / \mathrm{m}^{3}\right]$ & $14.1\left[\mathrm{~kg} / \mathrm{m}^{3}\right]$ & 1 \\
Flexural strength $^{\mathrm{b}}$ & $4.7\left[\mathrm{~N} / \mathrm{mm}^{2}\right]$ & $0.2\left[\mathrm{~N} / \mathrm{mm}^{2}\right]$ & 4 \\
Splitting tensile strength $^{\text {a }}$ & $3.5\left[\mathrm{~N} / \mathrm{mm}^{2}\right]$ & $0.5\left[\mathrm{~N} / \mathrm{mm}^{2}\right]$ & 14 \\
Modulus of elasticity $^{\mathrm{c}}$ & $33,600\left[\mathrm{~N} / \mathrm{mm}^{2}\right]$ & $1,100\left[\mathrm{~N} / \mathrm{mm}^{2}\right]$ & 3 \\
\hline${ }^{\text {a }} 15 \times 15 \times 15 \mathrm{~cm}^{2}$ cubes, ${ }^{\mathrm{b}} 10 \times 10 \times 40 \mathrm{~cm}^{2}$ prisms, ${ }^{\mathrm{c}}$ cylinder with $\varnothing 15 \mathrm{~cm}, 30 \mathrm{~cm}$ height
\end{tabular}

Top view

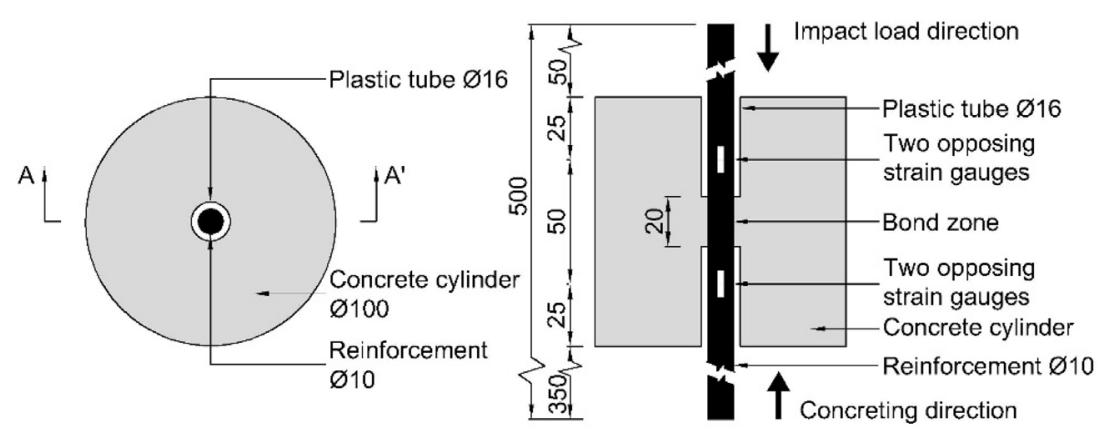

Figure 1: Cylindrical specimen used for push-in testing.

During the push-in testing, cylindrical specimens were used similarly to [17-19]. The specimens had $100 \mathrm{~mm}$ in diameter and their height was $100 \mathrm{~mm}$ (Fig. 1). The specimens were casted in a series of eight cylinders, four of which were used for testing in the servo-hydraulic machine and the remaining four were tested in the drop tower. The specimens together were casted in a joint formwork that allowed vertical concreting. The longer free end of the bar was pointing out of the base plate of the formwork. For this reason, the formwork had to be cantilevered from the vibrating table. The use of a compacting table ensured the same degree of compaction for all specimens. The specimens were compacted at a frequency of $50 \mathrm{~Hz}$. Throughout the experimental work deformed steel bars B500B confirming to [20] with a nominal diameter $\mathrm{d}_{\mathrm{s}}=10 \mathrm{~mm}$ were used. The average relative rib area $f_{R}$ of 0.072 was calculated from the measured values using the Simpson's rule formula [21]. The bond zone was located in the middle of the specimen and had a length of $2 \times d_{s}$, i.e. $20 \mathrm{~mm}$. The steel in the bond-free zone was divided from the concrete by a plastic tube with an outer diameter of 
$16 \mathrm{~mm}$ and a wall thickness of $1.5 \mathrm{~mm}$. Before the actual testing, the plastic tubes were removed so that they couldn't influence the measured results. The loading force was applied against the concreting direction.

The specimen sketch is shown in Fig. 1. In case of the specimens tested in the drop tower, two strain gauges opposite each other were glued on the rebar's longitudinal ribs before and after the bond zone. That means there were four strain gauges on every specimen. The strain gauges were covered with silicon for protection against moisture, and they were together with their leads covered by the plastic tube during concreting which ensured the bond-free zone. The strain gauges were $50 \mathrm{~mm}$ from each other leaving $15 \mathrm{~mm}$ between the bond zone and the centre of the gauge.

\subsection{Test set-up and procedures}

\subsubsection{Quasi-static loading}

Steel rebar push-in tests were performed in a servo-hydraulic loading machine under quasi-static loading conditions. The load was applied on top of the rebar as shown in Fig. 1 and the experimental set-up corresponded to the RILEM recommendations for pull-out testing [1] with a few modifications. The main modification is that in this experimental work the bar is pushed into the concrete cylinder instead of being pulled-out. According to Yan [14], the bond stress values of such tests might be slightly higher as the bar above the bond zone is under compression and thus its diameter increases due to the Poisson's effect. This leads to increased interlocking resistance of the bar in the bond zone. During the pull-out test, the bar is under tension and thus it becomes thinner, making it easier to pull it out of the concrete body. However for short-bond lengths, this effect becomes negligible [22]. Another modification was that the bond zone was located in the middle of the specimen and that its length was only two times the bar diameter. To check the influence in the two loading modes, quasi-static tests were performed in addition to the main test series. The difference in the loading direction proved to be negligible. During the quasi-static testing phase two loading rates were investigated:

1. $0.01 \mathrm{~mm} / \mathrm{s}$ according to RILEM recommendations,

3. $50 \mathrm{~mm} / \mathrm{s}$ to simulate intermediate loading rate.

During the quasi-static loading a force was measured by the internal load cell of the machine and the bond stress was calculated according to eqn. (1),

$$
\tau=\frac{F}{l_{b} \cdot \pi \cdot d_{s}}
$$

where $\tau$ is the bond stress, $F$ is the push-in force, $l_{b}$ is the length of the bond zone (in this case $2 \cdot d_{s}$ ) and $d_{s}$ is the steel reinforcement diameter.

The slip of the bar was measured contactless by utilizing optical extensometer. Black and white measuring marks were glued on the free end of the reinforcement and on the top edge of the concrete specimen, respectively. The marker on steal measured absolute movement of the rebar and the marker on concrete measured absolute movement of the concrete body. After subtracting these two signals, a relative displacement of the loaded end of the bar was calculated. To get the reinforcement slip in the bond zone, an elastic deformation of the bar 
between the marker on steel and the bond zone was subtracted from the measured relative displacement of the bar according to eqn. (2),

$$
s(t)=\Delta d(t)-\frac{F(t) \cdot l}{A_{s} \cdot E_{s}}
$$

where s is the rebar slip, $\Delta d$ is the measured relative displacement of the loaded end of the bar, $F$ is the acting force, $l$ is the distance between the marker and the bond zone (in this case $50 \mathrm{~mm}), A_{s}$ is the cross-sectional area of the rebar and $E_{s}$ is the steel's modulus of elasticity.

\subsubsection{Impact loading}

The push-in tests under impact loading were performed in a specially developed and instrumented drop tower. The drop tower is presented in [23], and it is capable of dropping an impactor from a height of $3.5 \mathrm{~m}$. The drop tower with the specimen is shown in Fig. 2. A data acquisition system capable of sampling the strain gauge amplifiers at the frequency of $1 \mathrm{MHz}$ was used. To eliminate the high frequency electrical noise in the strain gauge signals a Channel Frequency Class (CFC) 20,000 low-pass filter was used. The mathematical definition of the CFC filters can be found in SAE J211-1 [24, 25]. A cylindrical impactor with a diameter of $40 \mathrm{~mm}$ and a height of $500 \mathrm{~mm}$ was chosen for the push-in tests in order to produce a stress wave in the reinforcing steel as rectangular as possible. The mass of the impactor was $4.9 \mathrm{~kg}$, and it was made of hardened unalloyed carbon steel (Cf53 according to DIN 17212). The impactor moved in an aluminium tube and was pulled up by a manual pulley system. The impactor was attached to an electromagnet which was released before the impact test. The
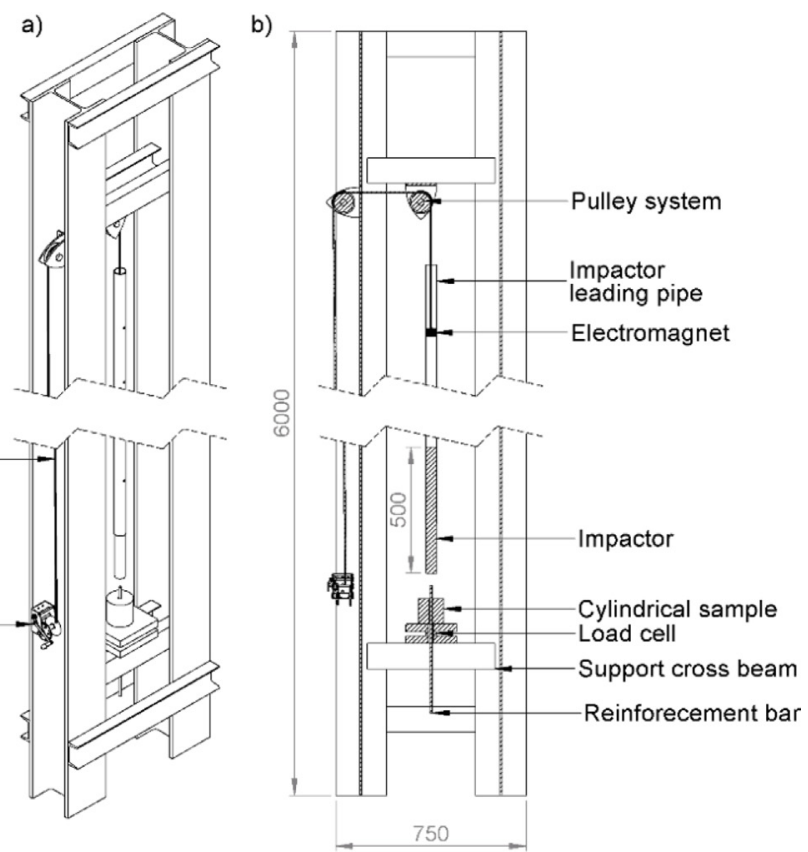

Figure 2: Drop tower testing equipment: (a) isometric view, (b) cross section. 
specimen was placed on an instrumental support which consisted of a piezoelectric load cell prestressed between two steel plates.

The signal from the load cell is influenced by the inertia of the concrete cylinder and was used to check the momentum equilibrium of the whole system. The bond stress in the case of impact loading can be derived from the change in the steel strain, and it was measured by strain gauges attached to the reinforcement bar. The rebar was $500 \mathrm{~mm}$ long to ensure enough time for measurement before the reflection of the stress wave at the free end. An even longer reinforcement bar would be desirable, however that would be very unpractical during concreting and handling. In case of a longer reinforcement bar, the bending moments induced during handling of the specimen could possibly destroy the bond zone.

The bond stress state between the reinforcing steel and concrete is shown in Fig. 3 on infinitesimally small element. From the equilibrium of forces on this differential element, the following equation can be written:

$$
\tau_{x} u_{s} d_{x}=d \sigma_{s} A_{s}
$$

After rewriting for $\tau_{x}$ and substituting $u_{s}, A_{s}$ and $\mathrm{d} \sigma_{\mathrm{s}}=E d \varepsilon_{\mathrm{s}}$ we get the following equation:

$$
\tau_{x}=\frac{d_{s} \cdot E_{s}}{4} \cdot \frac{d \varepsilon_{s}}{d_{x}}
$$

Under the assumption of constant bond stress for short-bond length, we can substitute the differential terms by $d \varepsilon_{s}=\varepsilon_{s, 1}-\varepsilon_{\mathrm{s}, 2}$ and $d_{x}=l_{b}=2 \cdot d_{s}$, and we get

$$
\tau_{x}=\frac{E_{s}}{8} \cdot\left(\varepsilon_{s, 1}-\varepsilon_{s, 2}\right)
$$

Equation 4 allows directly using the strain gauge signals from and thus minimizing the inertial effects of the specimen compared to the case with an external load cell. In quasi-static case, the strain in steel after the bond zone is zero $\left(\varepsilon_{s, 2}=0\right)$ and after substituting $\varepsilon_{s, 1}=F /\left(A_{s} \cdot E_{s}\right)$ into eqn. (5) we get eqn. (1) valid for the bond length $l_{b}=2 \cdot d_{s}$. The relative displacement of the reinforcement bar on the loaded end was measured with an optical extensometer in the same way as described in Chapter 3.2.1. The slip value at the bond zone was then calculated according to eqn. (2).

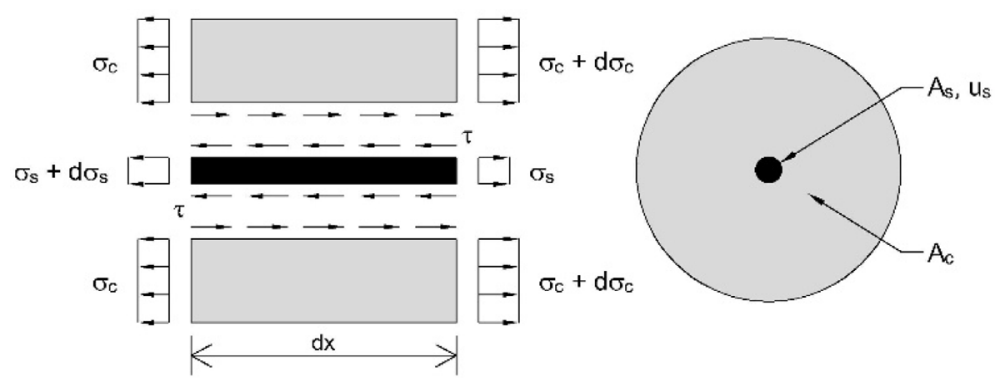

Figure 3: Differential element for bond between steel and concrete after [26]. 


\section{RESULTS AND DISCUSSION}

The loading rates and their corresponding bond stress rates can be found in Table 3. The loading rate is defined as the velocity of the machine crossbeam in case of hydraulic machine tests or the velocity of the impactor in case of the drop tower tests. Because the average bond stress rate is not linear, for the purpose of this paper, it is defined as the average bond stress increase over time between 2 and $12 \mathrm{~N} / \mathrm{mm}^{2}$. In this region, the bond stress increase is nearly linear. The average bond stress at the slip value of $0.9 \mathrm{~mm}$ is presented in Table 3 for simple comparison.

Because of the present experimental setup with a rebar length of $500 \mathrm{~mm}$, it is not possible to evaluate the bond stress after a slip value of $0.9 \mathrm{~mm}$ in case of dynamic experiments. The problem is that the time needed to reach higher slip values is too long. During this longer time, the stress wave reaches the free end of the rebar, is reflected and travels back as a tensile wave overlapping the incoming compressive stress wave. Because the distance between the strain gauges before and after bond zone is $50 \mathrm{~mm}$, there is a time lag between the two measurements. Until the reflected tensile wave reaches the top strain gauge, the bond stress calculated according to eqn. (5) is doubled. Also the reflected tensile wave passes for the

Table 3: Loading rates and average bond stress rates.

\begin{tabular}{lllll}
\hline \multirow{2}{*}{ Result } & \multirow{2}{*}{ Unit } & \multicolumn{3}{c}{ Type of loading } \\
\cline { 3 - 5 } & & Quasi-static slow & Quasi-static fast & Drop tower \\
\hline Loading rate & {$[\mathrm{mm} / \mathrm{s}]$} & 0.01 & 50 & 8,360 \\
$\begin{array}{l}\text { Average bond stress rate } \\
\text { Number of samples }\end{array}$ & - & 16 & 600 & $2 \times 10^{5}$ \\
$\begin{array}{l}\text { Average bond stress at } \\
\text { slip of 0.9 mm }\end{array}$ & {$\left[\mathrm{N} / \mathrm{mm}^{2}\right]$} & 0.25 & 12 & 12 \\
$\begin{array}{l}\text { Standard deviation at slip } \\
\text { of } 0.9 \mathrm{~mm}\end{array}$ & {$\left[\mathrm{~N} / \mathrm{mm}^{2}\right]$} & 3.14 & 21.4 & 25.0 \\
\hline
\end{tabular}
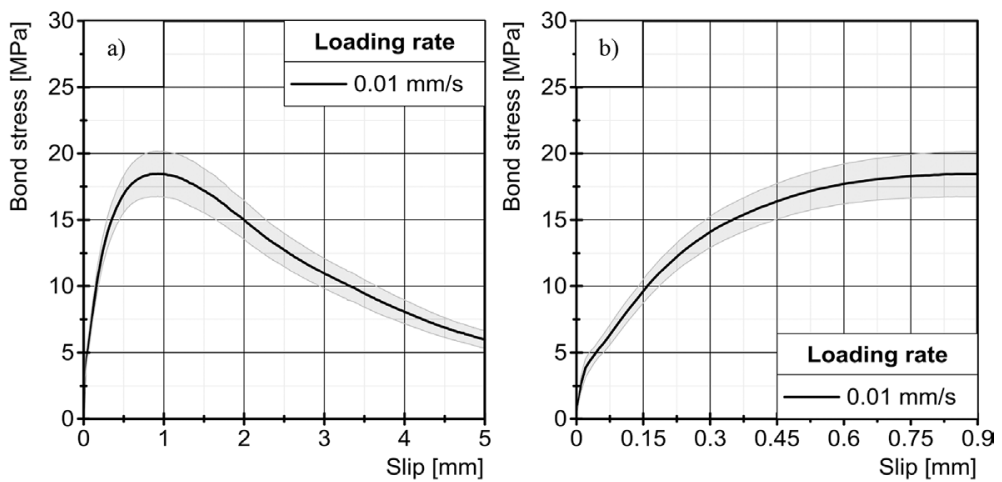

Figure 4: Results of quasi-static push-in tests: (a) complete bond stress-slip behaviour, (b) bond stress-slip relationship until the peak at $0.9 \mathrm{~mm}$ slip. 

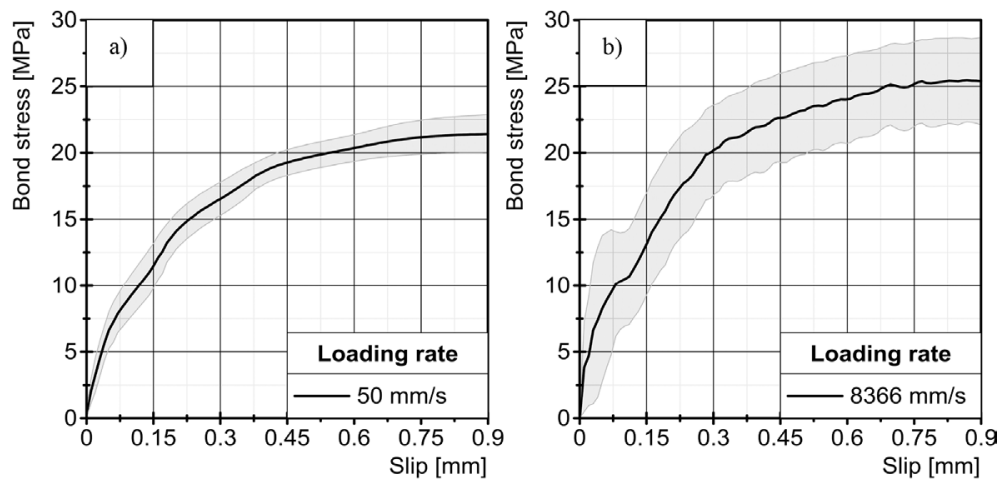

Figure 5: Bond stress-slip relationships for (a) intermediate and (b) high-loading rates.

second time through the damaged bond zone. As the friction in the damaged bond zone is not known, it is hard to separate the reflected wave from the incoming wave. In addition, the slip value of $0.9 \mathrm{~mm}$ is high enough to consider the bond zone as failed. This can be seen in Fig. 4 where quasi-static results of bond stress against slip are presented. In Fig. 4a, the bond stress behaviour until the slip value of $5 \mathrm{~mm}$ is presented. In Fig. $4 \mathrm{~b}$ the dependence of bond stress on slip until $0.9 \mathrm{~mm}$ is depicted. From Fig $4 \mathrm{a}$, it can be seen that the ultimate bond stress is reached at a slip of $0.9 \mathrm{~mm}$.

Figure 5 shows the bond stress against slip relationship until the slip value of $0.9 \mathrm{~mm}$ for the tests with higher loading rates. The bond stress-slip curves presented in Figs 4 and 5 represent average bond stresses from 16 and 12 specimens for quasi-static and dynamic tests, respectively. The averages were evaluated at a defined slip increment of $0.01 \mathrm{~mm}$. The shaded areas in Fig. 4 and 5 represent the confidence range for the calculated average between 5\% and $95 \%$. The push-in failure mode was in all cases caused by shearing of the concrete cantilevers between the ribs. During the experimental work, splitting of the specimens never occurred. After the push-in tests were finished the specimens were cut in two halves and the bond zone was examined. The area between the ribs was completely smooth and no cracking pattern in the concrete body could be macroscopically observed. It was found that there was no visual difference in the state of the bond zone based on the loading rate.

\section{CONCLUSIONS}

When comparing Figs 4 and 5 and based on the results presented in Table 3, an increase in the average bond stress at higher loading rates can be observed. This increase in bond stress can be interpreted as a dynamic increase factor (DIF), however, it is important to note that the variance of pull-out and push-in tests is around $20 \%$ even under quasi-static loading conditions [27]. It is well known that in case of dynamic loading this variance even increases [19]. This was also observed during this experimental work, especially for the drop tower loading scenario.

The average DIF determined during the experimental work was 1.54 for bond stress rates in the order of $2 \times 10^{5} \mathrm{~N} / \mathrm{mm}^{2} \cdot \mathrm{s}$. This value is comparable to the DIF presented in literature. For instance Michal et al. [28] performed recently push-in tests in a split Hopkinson bar for concrete with a compressive strength $f_{c}=50.5 \mathrm{~N} / \mathrm{mm}^{2}$ which is similar to the concrete used in this study. They investigated deformed reinforcement bars with a diameter of $10 \mathrm{~mm}$ and a bond length of $40 \mathrm{~mm}$. For a bond stress rate of $1.57 \times 10^{5} \mathrm{~N} / \mathrm{mm}^{2} \cdot \mathrm{s}$ they reported a DIF of 
1.45. Similar results reported Reinhardt [19] for concrete with a compressive strength of 50 $\mathrm{N} / \mathrm{mm}^{2}$. He reported results only until the slip of $0.2 \mathrm{~mm}$ with a DIF of 1.25 . Reinhardt also suggested that the DIF is higher for lower concrete grades and lower slip values.

The knowledge of bond stress-slip behaviour is important for the design of structures subjected to high-loading rates, especially with respect to crack widths. A finite element model will be introduced in the future work, which will allow to describe local stress state in the bond zone. To describe the behaviour at even higher loading rates, split Hopkinson bar configuration will be used to perform push-in tests. In addition, the drop tower in pull-out configuration will be used in future work to have direct comparison to the standard tests.

\section{ACKNOWLEDGEMENT}

The presented project was funded by the German Federal Ministry of Economic Affairs and Energy (BMWi, project no. 1501486) on the basis of a decision by the German Bundestag.

\section{REFERENCES}

[1] RILEM, Technical Recommendations for the Testing and Use of Construction Materials, E\&FN Spon: London, 1994.

[2] Bischoff, P., Stress-strain relationship of reinforced concrete subjected to biaxial tension. ACI Structural Journal, 102, pp. 169-170, 2005.

[3] Malvar, L.J., Review of static and dynamic properties of steel reinforcing bars. ACI Materilas Journal, 95(5), pp. 609-614, 1998.

[4] Cadoni, E., Fenu, L. \& Forni, D., Strain rate behaviour in tension of austenitic stainless steel used for reinforcing bars. Construction and Building Materials, 35, pp. 399-407, 2012.

http://dx.doi.org/10.1016/j.conbuildmat.2012.04.081

[5] ACI Committee 466, Report on dynamic fracture of concrete, 2004.

[6] Comité euro-international du béton, Concrete structures under impact and impulsive loading, 1988.

[7] Bischoff, P.H. \& Perry, S.H., Compressive behaviour of concrete at high strain rates. Materials and Structures, 24(6), pp. 425-450, 1991.

http://dx.doi.org/10.1007/BF02472016

[8] Quast, M. \& Curbach, M., Behaviour of concrete under biaxial dynamic loading. In Fifth International Workshop on Performance, Protection \& Strengthening of Structures under Extreme Loading, East Lansing, p. 8, 2015.

[9] Hansen, R.J. \& Liepins, A.A., Behavior of bond under dynamic loading. Journal Proceeding, 59, pp. 563-582, 1962.

[10] Shah, K. \& Hansen, R.J., Behavior of bond under dynamic loading. Journal of American Concrete Institue, 59, 1963.

[11] Hjorth, O., Ein Beitrag zur Frage der Festigkeiten und des Verbundverhaltens von Stahl und Beton bei hohen Beanspruchungsgeschwindigkeiten, Techische Universität Braunschweig, 1976.

[12] Vos, E. \& Reinhardt, H.W., Influence of loading rate on bond behaviour of reinforcing steel and prestressing strands. RILEM, 15, pp. 3-10, 1982. http://dx.doi.org/10.1007/bf02473553

[13] Vos, E., Influence of Loading Rate and Radial Pressure on Bond in Reinforced Concrete - A Numerical and Experimental Approach, Technical University Delft, 1983. http://dx.doi.org/10.1007/bf02473553 
[14] Yan, C., Bond Between Reinforcing Bars and Concrete Under Impact Loading, The University of British Columbia, 1992.

[15] Weathersby, J.H., Investigation of Bond Slip Between Concrete and Steel Reinforcement Under Dynamic Loading Conditions, Louisiana State University, 2003.

[16] Solomos, G. \& Berra, M., Rebar pullout testing under dynamic Hopkinson bar induced impulsive loading. Materials and Structures, 43, pp. 247-260, 2010. http://dx.doi.org/10.1617/s11527-009-9485-z

[17] Solomos, G. \& Berra, M., Testing of anchorages in concrete under dynamic tensile loading. Materials Structures, 39, pp. 695-706, 2006. http://dx.doi.org/10.1617/s11527-006-9112-1

[18] Michal, M. \& Keuser, M., Bond of steel and concrete under high loading rates. Proceeding 9th Int. Conference Structural Dynamics, pp. 3491-3496, 2014.

[19] Reinhardt, H.W., Concrete Under Impact Loading, Tensile Strength and Bond, Delft University of Technology, 27, pp. 1-48, 1982.

[20] DIN Deutsches Institut für Normung, DIN 488-2 Betonstahl-Betonstabstahl, 2009.

[21] Comité Européen de Normalisation, EN ISO 15630-1: Steel for the Reinforcement and Prestressing of Concrete. Test Methods - Part 1: Reinforcing Bars, Wire Rod and Wire, Geneva, Switzerland, 2010.

[22] Ruiz, M.F., Muttoni, A. \& Gambarova, P., Analytical modeling of the pre- and postyield behavior of bond in reinforced concrete. ASCE Journal of Structural Engineering, 133(10), pp. 1364-1372, 2007. http://dx.doi.org/10.1061/(ASCE)0733-9445(2007)133:10(1364)

[23] Máca, P., Sovják, R., Konvalinka, P. \& Curbach, M., Design of ultra high performance fibre reinforced concrete mixture and its behaviour under impact loading. In Performance, Protection and Strengthening of Structures Under Extreme Loading, The indian concrete journal: Thane, 2013.

[24] Society of Automotive Engineers, SAE J211/1: Instrumentation for Impact Test, Part 1, Electronic Instrumentation, Warrendale, PA, 1995.

[25] Nabih, A. \& Matthew, P., Design of Digital Low-pass Filters for Time-Domain Recursive Filtering of Impact Acceleration Signals, Fort Rucker, Alabama, 1995.

[26] Krips, M., Rißbreitenbeschränkung im Stahlbeton und Spannbeton. In Mitteilungen aus dem Institut für Massivbau der Technischen Hochschule Darmstadt, Ernst \& Sohn: Berlin, 1985.

[27] Zilch, K. \& Zehetmaier, G., Bemessung im konstruktiven Betonbau, Springer-Verlag Berlin/Heidelberg: Berlin, Heidelberg, 2010.

[28] Michal, M., Keuser, M. \& Milon, O., Verbund von Beton und Bewehrungsstahl bei hoch-dynamischer Belastung. Beton- und Stahlbetonbau, 111(1), pp. 32-40, 2016. http://dx.doi.org/10.1002/best.201500050 